\title{
Systematic Review of Good Teaching Practices with ICT in Spanish Higher Education. Trends and Challenges for Sustainability
}

\author{
Santiago Alonso-García ${ }^{\mathbb{D}}$, Inmaculada Aznar-Díaz ${ }^{\mathbb{D}}$, María-Pilar Cáceres-Reche ${ }^{\mathbb{D}}$, \\ Juan-Manuel Trujillo-Torres $(\mathbb{D}$ and José-María Romero-Rodríguez *(D) \\ Department of Didactics and School Organization, University of Granada, 18071 Granada, Spain; \\ salonsog@ugr.es (S.A.-G.); iaznar@ugr.es (I.A.-D.); caceres@ugr.es (M.-P.C.-R.); jttorres@ugr.es (J.-M.T.-T.) \\ * Correspondence: romejo@ugr.es; Tel.: +34-958-246-687
}

Received: 17 November 2019; Accepted: 11 December 2019; Published: 13 December 2019

\begin{abstract}
Good teaching practices are developed in order to improve student learning. With technological and social development, educational practices increasingly demand the use of technology, so having good teaching practices with Information and Communication Technologies (ICT) is essential. At the same time, the Sustainable Development Agenda of the United Nations for the year 2030 is setting the principles of sustainable action for today's society. In this context, the following objectives were proposed: to identify the good teaching practices with ICT that are being developed in Spanish higher education and to establish the relationship between good teaching practices with ICT and the Sustainable Development Goals (SDG). For this purpose, the method of systematic review of the literature based on the PRISMA protocol was used. A total of 27 documents published in the period 2008-2019 on good teaching practices with ICT in Spanish higher education were analyzed. Among the results, the emerging trend of good practices with ICT, the use of a Virtual Learning Environment (VLE) as the main technology in good practices, and the majority of good practices in the development of SDG \#4 (Quality Education) are highlighted. Finally, it is a challenge for teachers to include all these aspects in their classroom teaching.
\end{abstract}

Keywords: good teaching practices; ICT; higher education; sustainability; systematic review

\section{Introduction}

Technological development has had a major impact on education in the twenty-first century. The pedagogical proposals using Information and Communication Technologies (ICT) are numerous and growing exponentially. These technological trends in education are collected annually through the Horizon Report. The trend for higher education in the next five years (2019-2023) links the application of mobile learning, analytical technologies, mixed reality, artificial intelligence, blockchain, and virtual assistants [1].

Although some of these technologies seem utopian, different ICT-based methodologies are currently being implemented, due to which e-learning [2,3], blended-learning [4,5], flipped classrooms [6,7], and mobile learning $[8,9]$ are booming.

E-learning has encompassed everything concerning e-learning, mainly through the Virtual Learning Environment (VLE) [10]. At the same time, models oriented towards blended learning have been developed in order to overcome the limitations of totally virtual teaching [11]. In this space the flipped classroom method also coexists, a variant of b-learning, where the student acquires greater control and becomes the main actor in learning [12]. Also with the development of mobile technology, 
mobile learning is increasingly using mobile devices to develop learning content and active dynamics in the classroom [13].

However, technology training and teacher collaboration have a positive association with the use of ICT in the classroom $[14,15]$. So these aspects are fundamental to developing innovative practices with technology. However, the frequency of ICT use in Spanish universities is low due to factors such as technological competence, age, and experience $[16,17]$. This study highlights the use of different technological resources depending on the area of knowledge: the majority of forums, blogs, and wikis are used in Arts and Humanities, while virtual platforms are mostly applied in Social and Legal Sciences as well as Sciences.

On the other hand, in recent times, the interest of teachers in including technological innovations in the classroom has led to them compiling good teaching practices that serve as a reference [18]. Thus, the concept of good practice refers to the activities that use ICT effectively, leading to satisfactory results (involvement, motivation, and skills development) and are reference practices that can be transferred to other contexts. In this way, good teaching practices with ICT allow the transformation of educational practices into more collaborative, interactive, and motivating models for the student [19].

In this context of change, virtual education is fundamental in higher education, especially since the establishment of the European Higher Education Area (EHEA), where has been stated that learning must be student-centered [20]. Some initiatives include the development of virtual activities based on models of good teaching practices [21]. While other initiatives focus on the use of ICT to solve the problems presented by language teaching, they are also included as models of good practice [22].

On the other hand, some authors have established that there must be a series of principles for the use of ICT to be a good teaching practice. As a result, the model established by Chickering and Gamson [23] includes seven principles:

1. Stimulate contact between teachers and students.

2. Develop cooperation between the students.

3. Use active learning techniques.

4. Provide immediate feedback.

5. Allow tasks to be carried out on schedule.

6. Communicate positive expectations.

7. Respect the diversity of capacities and modes of learning.

Although these indicators were established more than 30 years ago, they are still used to identify good teaching practices with ICT, and it is essential that all of them are present for categorization.

Referring to the Spanish context, the studies on good teaching practices developed at the Spanish University have concluded with the compilation of models of teaching activity and key aspects for their identification. In this sense, Marcelo, Yot, and Mayor [24] analyzed the experiences of 58 teachers from Andalusian universities and compiled them in the repository Alacena. Cabero et al. [25], examined good teaching practices with ICT in Spanish universities by identifying a number of centers that are examples of good teaching practices. Martí et al. [26], focused on detecting successful experiences in order to highlight a series of specific practices of the good use of ICT in university education at the University of the Balearic Islands. And Prendes and Gutiérrez [27], analyzed the Spanish public universities and established a catalogue of indicators of good teaching practices with ICT.

As for the previous studies of systematic review of good teaching practices, none have approached the object of study from the perspective of ICT nor have they focused solely on a Spanish University. The studies carried out have also focused on: analyzing best engineering teaching practices in India [28]; identifying good teaching practices in the use of mobile devices in primary education [29]; analyzing good teaching practices in anatomy [30], and highlighting best teaching practices to prepare social work students to work with racial and ethnic groups [31].

Lastly, along the lines of educational improvement, the Sustainable Development Goals (SDG) are beginning to be linked to different educational areas. The SDG have been defined by the United 
Nations (UN) as part of its Sustainable Development Agenda 2030 [32], establishing a total of 17 goals where education and ICT are key to their achievement [33]. Among the 17 goals, the one most directly related to education is the SDG \#4: Quality Education.

In this context, sustainability is a fundamental aspect that should be included as an indicator of good teaching practices with ICT [34]. In particular, the use of the potential of ICT to achieve SDG \#4 [35] should be an area of focus, where each University should manage its good teaching practices for the correct use of ICT, based on the human capital that they possess [36].

Finally, based on different theoretical contributions, the established objectives of the study were: (i) identify the good teaching practices with ICT that are being developed in Spanish higher education and; (ii) establish the relationship of good teaching practices with ICT with the SDG. In turn, the research questions that guided and structured the analysis process were:

RQ1. How many studies were published over the years?

RQ2. What have been the good teaching practices with ICT?

RQ3. In what fields of knowledge have good teaching practices with ICT been developed?

RQ4. What technology has been used in the development of good teaching practices?

RQ5. Which institutions have developed good teaching practices with ICT?

RQ6. What SDG was developed in good teaching practices with ICT?

\section{Methods}

The systematic literature review method was used to address the objectives of this paper [37-39]. The systematic review was supported by the quality criteria established in the PRISMA statement (Preferred Reporting Items for Systematic reviews and Meta-Analyses) [40]

The review process followed consisted of two stages (planning and action). This protocol consisted of defining the research questions, the inclusion and exclusion criteria, and the establishment of descriptors and databases (planning stage). Subsequently, in the action phase, we proceeded to search for references in the selected databases, to refine the data through filters, and to extract the information in order to finally perform the representation of the data.

The inclusion and exclusion criteria were formulated based on the study objectives and the RQs based on the recommendations of the PRISMA statement [40] (Table 1).

Table 1. Inclusion and exclusion criteria.

\begin{tabular}{ll}
\hline \multicolumn{1}{c}{ Inclusion Criteria (IC) } & \multicolumn{1}{c}{ Exclusion Criteria (EX) } \\
\hline IC1: Journal articles. & $\begin{array}{l}\text { EX1: Book chapters, books, or other types of } \\
\text { non-peer-reviewed publications. }\end{array}$ \\
\hline IC2: Empirical research. & EX2: Theoretical studies or revisions. \\
\hline IC3: Articles written in English or Spanish language. & $\begin{array}{l}\text { EX3: Articles are not written in English or Spanish } \\
\text { language. }\end{array}$ \\
\hline $\begin{array}{l}\text { IC4: Research discusses good teaching practice } \\
\text { with ICT. }\end{array}$ & $\begin{array}{l}\text { EX4: Research does not discuss good teaching } \\
\text { practices with ICT. }\end{array}$ \\
\hline $\begin{array}{l}\text { IC5: Practices that have been implemented in Higher } \\
\text { Education. }\end{array}$ & $\begin{array}{l}\text { EX5: Practices that have not been implemented in } \\
\text { Higher Education. }\end{array}$ \\
\hline $\begin{array}{l}\text { IC6: Good teaching practices with ICT that have been } \\
\text { developed in Spain. }\end{array}$ & $\begin{array}{l}\text { EX6: Good teaching practices with ICT that have not } \\
\text { been developed in Spain. }\end{array}$ \\
\hline
\end{tabular}

\subsection{Search Strategy}

The search strategy focused on the Web of Science (WOS) and SCOPUS databases. The selection of these databases was motivated by their international prestige and the quality standards they use to index articles [41]. Thus, once the databases were selected, the descriptors were established and the 
search equations were formed (Table 2). In order to do this, the main focus was on indexing the terms in the UNESCO and ERIC thesauri and their use in the scientific community based on the articles published with the greatest impact on this topic [42-44].

Table 2. Search topics.

\begin{tabular}{|c|c|}
\hline Database & Search Descriptors \\
\hline WOS & $\begin{array}{l}\text { TS = ("good practices" OR “good teaching practices" OR “good educational practices" OR } \\
\text { "best practices" OR “best teaching practices" OR “best educational practices") AND TS = (ICT } \\
\text { OR “Information and Communication Technolog *" OR “Emerging technologies" OR } \\
\text { technolog * OR Internet) AND TS = (Universit * OR College * OR “Higher Education" OR } \\
\text { Postsecondary * OR Undergraduate *) } \\
\text { Document type = article } \\
\text { Time period = all years } \\
\text { Country/territory = Spain } \\
\text { Index = SCI-EXPANDED, SSCI, AandHCI, CPCI-S, CPCI-SSH, BKCI-S, BKCI-SSH, ESCI, } \\
\text { CCR-EXPANDED, IC }\end{array}$ \\
\hline SCOPUS & $\begin{array}{l}\text { TITLE-ABS-KEY ("good practices" OR "good teaching practices" OR “good educational } \\
\text { practices" OR “best practices" OR "best teaching practices" OR “best educational practices") } \\
\text { AND TITLE-ABS-KEY (ICT OR “Information and Communication Technolog " OR "Emerging } \\
\text { technologies" OR technolog * OR Internet) AND TITLE-ABS-KEY (Universit * OR College * } \\
\text { OR "Higher Education" OR Postsecondary * OR Undergraduate *) } \\
\text { Document type = article } \\
\text { Time period = all years } \\
\text { Country/territory = Spain }\end{array}$ \\
\hline
\end{tabular}

Note: * is used in order not to narrow down the search term and to be able to collect all the keywords that begin with those words.

Two independent researchers were involved in the selection of the articles and followed the guidelines established in the search protocol. This reduced study selection bias [41]. The degree of agreement of the researchers in the selection of the studies was $100 \%$.

\subsection{Data Collection and Analysis}

Data collection involved the PRISMA protocol, where the screening process was divided into the four established phases (Figure 1). It started in the identification phase that included all the articles found after applying the search equation of Table 2 in WOS and SCOPUS. In the next phase, the screening phase, the number of articles was reduced with the elimination of duplicate citations and the application of the inclusion and exclusion criteria. Subsequently, in the suitability phase, the texts of the articles were analyzed for the key information set out in the RQs. The inclusion (IC4, IC5, and IC6) and exclusion (EX4, EX5, and EX6) criteria were applied exhaustively in this phase, where some articles were discarded due to non-compliance with the inclusion criteria and compliance with the exclusion criteria. Finally, the inclusion phase collected the articles that make up the study sample. The search was conducted on 6 November 2019 and included all articles published to date.

With regard to data processing, they were grouped and analyzed with the help of Microsoft Excel software (Microsoft, Washington, DC, USA), Professional Plus 2013 version. The graphs were elaborated with the software Tableau (Tableau Software, Washington, DC, USA), version 2019.3. 

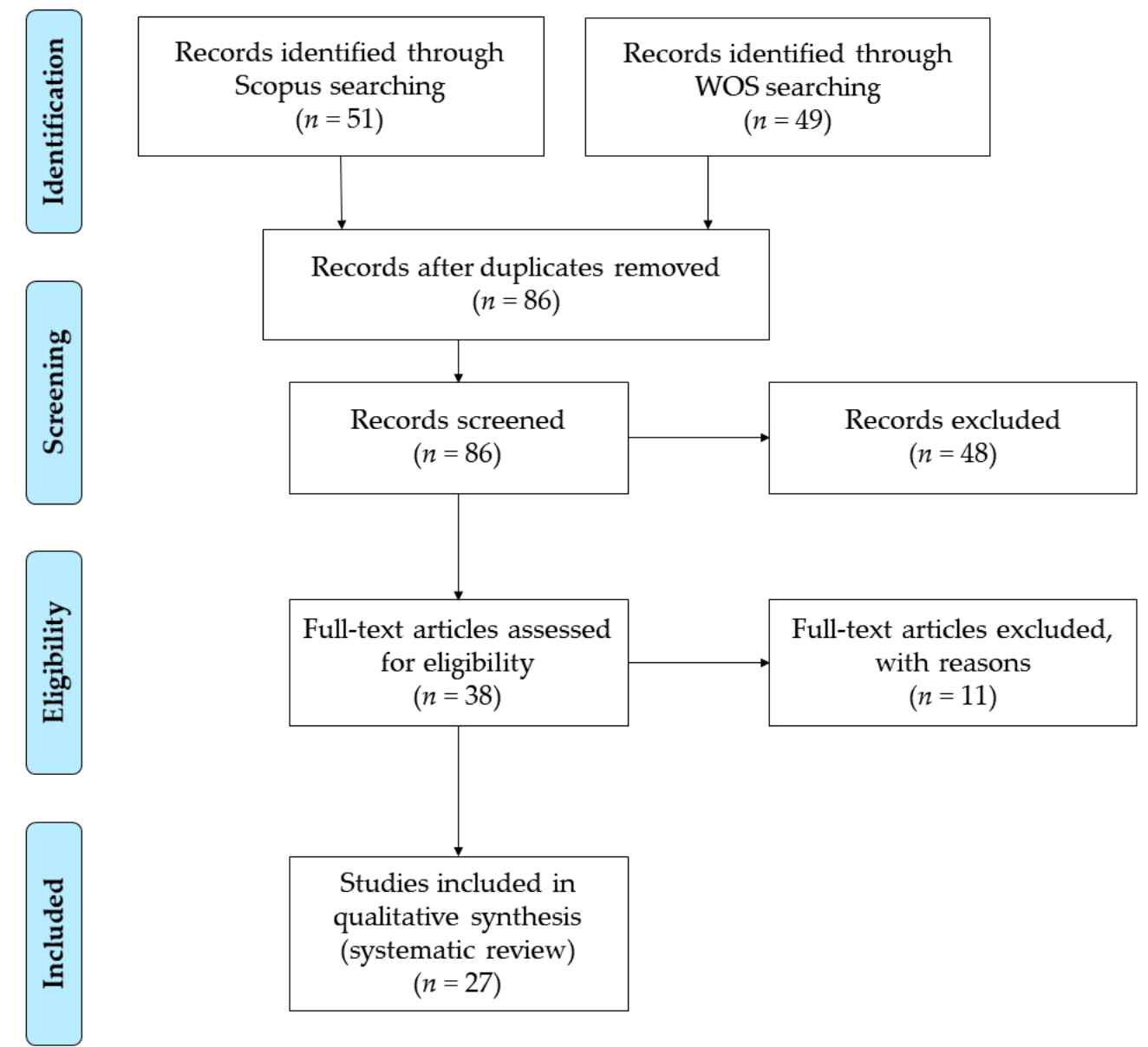

Figure 1. Flow diagram.

\section{Results}

3.1. RQ1. How Many Studies were Published over the Years?

A total of 27 articles met the objectives of the study and the inclusion and exclusion criteria. The first of these dates back to 2008, and from that year onwards, the relevant theme has been developed. However, most of the production took place in the last four years (55.56\%). WOS collected a total of 12 studies (44.44\%) and SCOPUS collected a total of 15 papers (55.56\%) (Figure 2). 


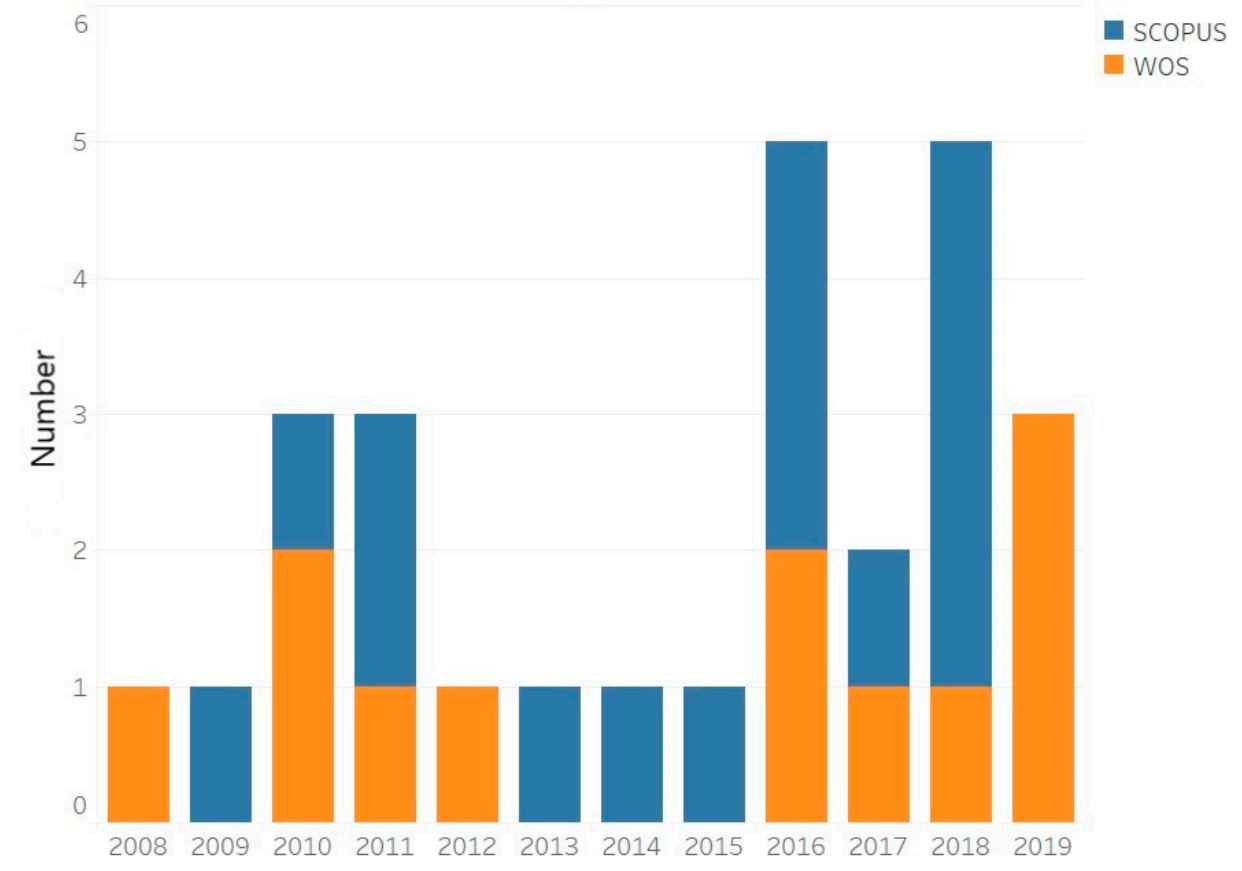

Figure 2. Grouping of articles by year and database.

\subsection{RQ2. What were the Good Teaching Practices with ICT?}

Each experience developed a different dynamic and was unique. However, in all of them there are common aspects that characterized them as a good teaching practice: (i) the focus of the activity was on the student, (ii) they encouraged collaborative work, and (iii) they favored autonomy. The following is a synthesis of each good teaching practice with ICT:

- We worked on the content of the subject relating it to the SDG through the use of technology, online surveys and peer review [45].

- VLE that presented the content in different formats offers variation of activities and develops fluid and constant communicative processes between teachers and students, as well as between peers [46]

- VLE based on the methodological principles of autonomy, cooperation, and interaction [47]

- A multicultural approach to the subject with textual and audiovisual resources, promotion of self-employment, and webconferencing [48].

- $\quad$ Task-based language learning with the use of ICT [49].

- Online activities designed to support feedback, while face-to-face peer interaction and collaboration were promoted (a blended learning method) [50].

- Implementation of blended learning, where the platform collected a variety of materials and formats (text, audio, video, etc.) [51]

- Development of a collaborative inter-university MOOC [52,53].

- Use of radio as an element of citizen participation and an education-communication strategy in the infant stage [54].

- Media workshops focused on distinguishing the possibilities between different media [55].

- The use of mobile devices in language learning with content that favored collaboration, peer review, and gamification of teaching [56].

- The use of podcasting to develop a wide range of student skills and support learning [57].

- Application of a multilingual app for smartphones based on communication needs [58].

- More interactive VLE for computer-assisted language testing [59].

- The use of a VLE for university tutoring [60].

- VLE that favored collaborative work [61]. 
- The use of PyramidApp which provided flexible and collaborative learning spaces [62].

- VLE with additional material, student feedback, online exams, collaborative work (forums and wikis), and gamification [17].

- Training using highly specialized footwear CAD technologies with 3D technology [63].

- The use of real recordings of legal-labour processes to encourage autonomous work in Law [64].

- Virtual exchange and telecollaboration through a VLE [65].

- The use of video as a complement to the masterclass in Engineering [66].

- The use of mobile devices with the aim of developing informational skills in students of the Infant and Primary Education grades [67].

- The use of Moodle, Google Drive, and collaborative platforms that favored the exchange of information between peers [68].

- VLE with student-centered educational and technological standards [69].

- Development of a tutorial for university libraries based on key aspects of good tutorial practices, with a special emphasis on interactivity [70].

\subsection{RQ3. In What Field of Knowledge have Good Teaching Practices with ICT been Developed?}

The fields of knowledge were grouped into five categories, according to the guidelines of scientific branches of the University of Granada for undergraduate studies: 1. Arts and Humanities; 2. Sciences; 3. Health Sciences; 4. Social and Legal Sciences; and 5. Engineering and Architecture. The degrees included in each field of knowledge can be consulted on the following website (https: //www.ugr.es/estudiantes/grados).

After establishing the five categories, four of them were detected in the studies analyzed. The Health Sciences field did not collect any good teaching practices involving ICT. In contrast, most good practices have been developed in the scientific field of Social and Legal Sciences (62.96\%) [17,45-48, 51-55,60-62,64,67,68,70], followed by Arts and Humanities (18.51\%) [49,56,58,59,65], Engineering and Architecture (14.81\%) $[57,63,66,69]$ and finally, to a lesser extent, the Sciences $(3.70 \%)$ [50]. The trend in each of them has been different. The Social and Legal Sciences have a longer path and currently the publications on good teaching practices with ICT in this area of knowledge have been well maintained, while in the other fields no publications were collected in 2019. The most recent publication date was 2018 in the case of Arts and Humanities, Engineering and Architecture in 2016, and Sciences in 2015 (Figure 3).

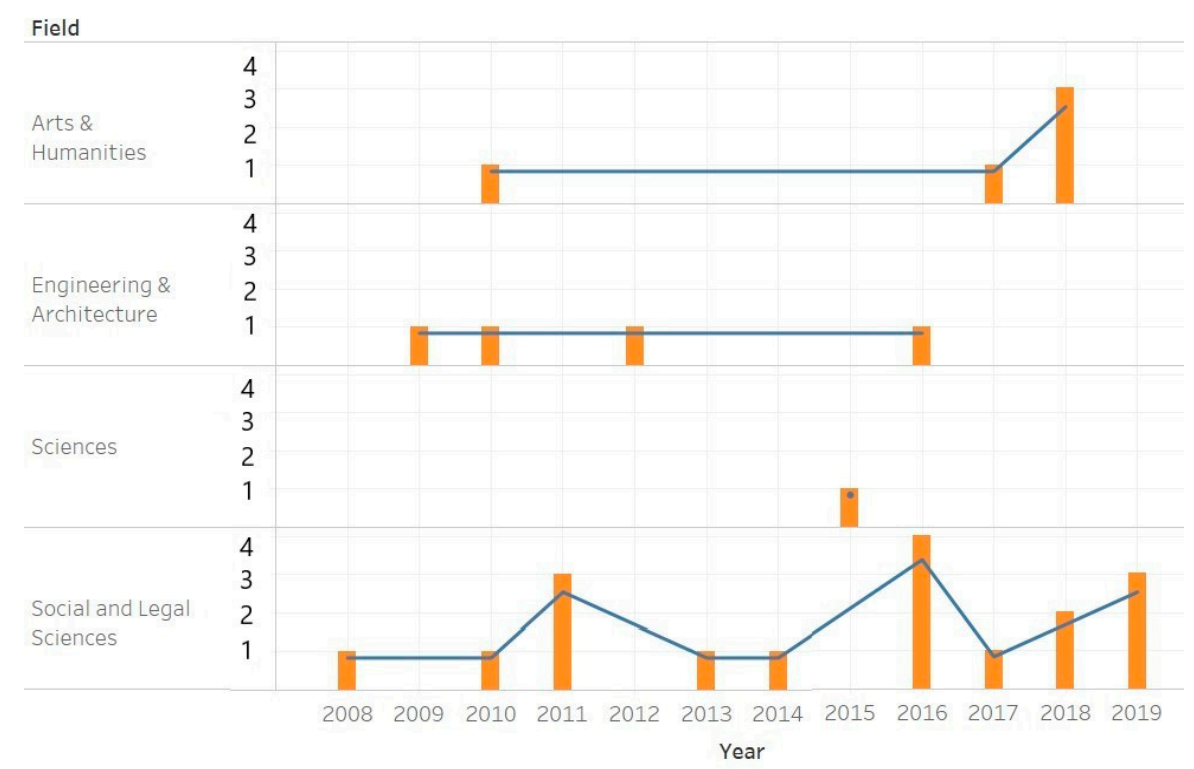

Figure 3. Field of knowledge where good teaching practices with ICT have been developed by year. 


\subsection{RQ4. What Technology has been Used in the Development of Good Teaching Practices?}

In Spanish universities, good teaching practices with VLE (59.25\%) [17,45-53,59-61,65,68,69], have been highlighted. Its use has predominated over other technologies: mobile devices (14.81\%) [56,58,62, 67], Podcasting (7.40\%) [57,64], Radio (7.40\%) [54,55], Video (3.70\%) [66], 3D (3.70\%) [63], and Web $(3.70 \%)$ [70]. At the same time, the greatest variety of technologies used is found in the field of Social and Legal Sciences with five different technologies, followed by Engineering and Architecture with four, Arts and Humanities with two, and Sciences with one (Figure 4).

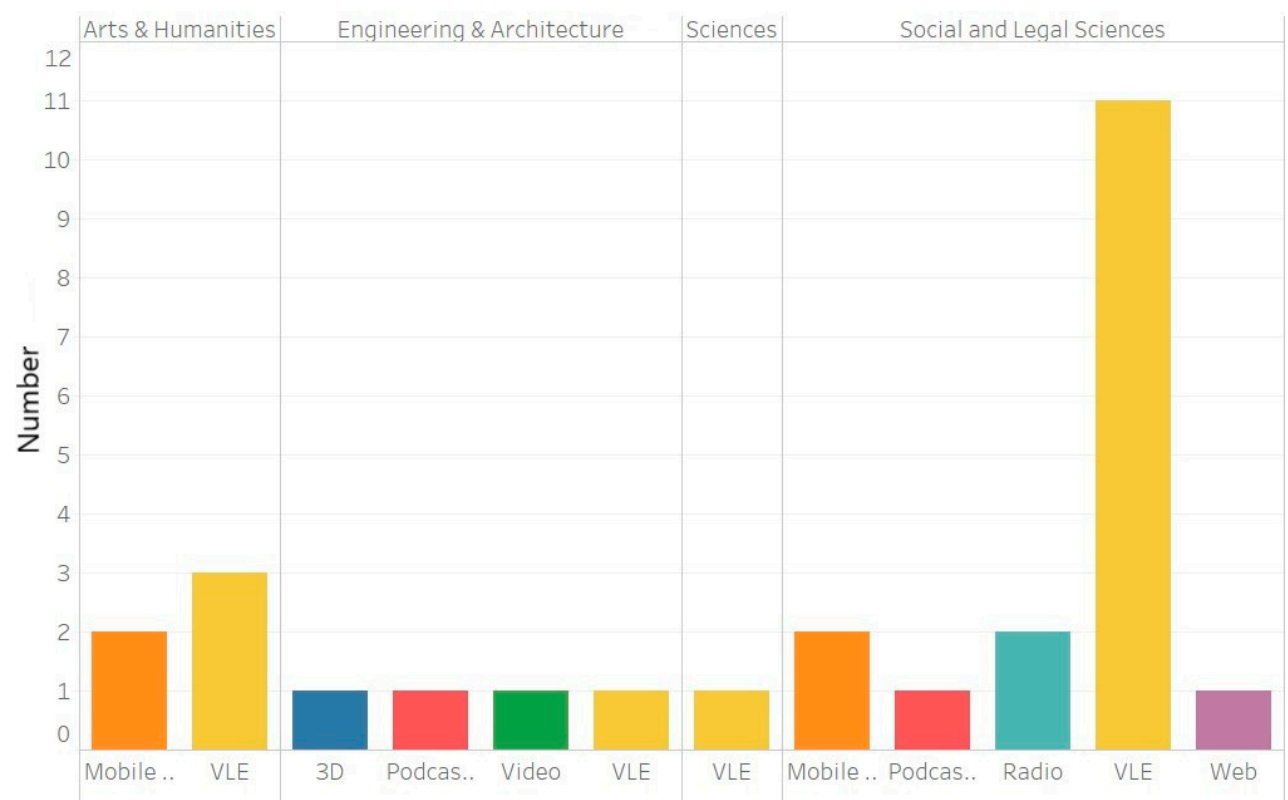

Figure 4. Technologies used in good teaching practices with ICT by field of knowledge.

On the other hand, the use of each of the technologies has had a different diachronic trajectory. In this regard, 3D technology, radio, video, and web have been used at specific times. Podcasting had its boom during the years 2009-2011. Mobile devices are the most recent technology included, with a start in 2018 and maintenance in 2019. And the one with the longest route is the VLE, which began in 2008 and whose usage has remained stable in recent years (Figure 5).

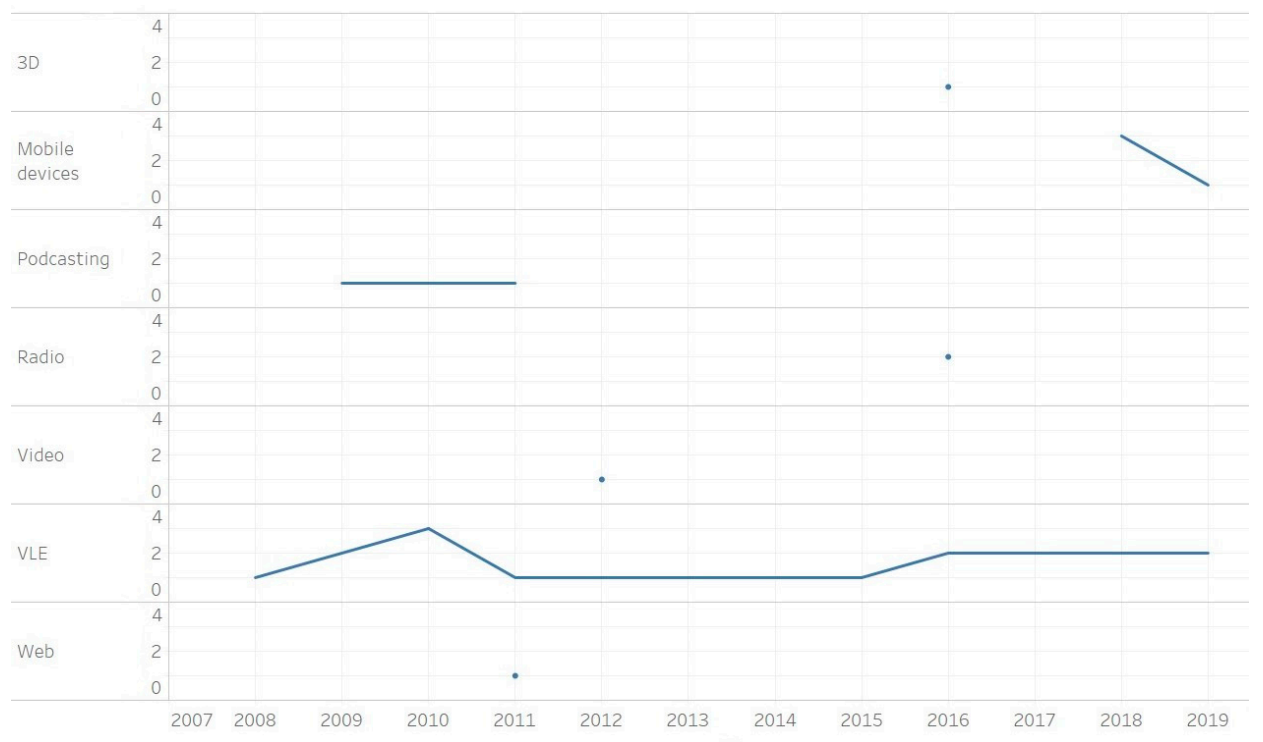

Figure 5. Technologies used in good teaching practices with ICT by year. 


\subsection{RQ5. Which Institutions have Developed Good Teaching Practices with ICT?}

Good teaching practices with ICT have been developed in a total of 20 higher education institutions (Table 3). The University of Granada (UGR) and National University of Distance Education (UNED) have been the ones that has developed more experiences with diverse technologies $(n=3)$. On the other hand, only five centers have developed two experiences (UC, UNIOVI, USAL, and UVIGO) and the majority of institutions collected only a single good teaching practice. Furthermore, each center has applied a single technology except the UGR, UNED, USAL, and UVIGO that show experiences where different technologies have been applied.

Table 3. Institutions and technology used in good teaching practices with ICT.

\begin{tabular}{|c|c|c|}
\hline Institution & $n$ & Technology \\
\hline [63] INESCOP & 1 & $3 \mathrm{D}$ \\
\hline [59] University of Alcalá de Henares (UAH) & 1 & VLE \\
\hline [52,53] University of Cantabria (UC) & 2 & VLE \\
\hline [61] University of Extremadura (UNEX) & 1 & VLE \\
\hline$[49,64,67]$ University of Granada (UGR) & 3 & PD, MD, VLE \\
\hline [54] University of Huelva (UHU) & 1 & Radio \\
\hline [46] University of La Laguna (ULL) & 1 & VLE \\
\hline [65] University of León (UNILEON) & 1 & VLE \\
\hline [55] University of Malaga (UMA) & 1 & Radio \\
\hline [52,53] University of Oviedo (UNIOVI) & 2 & VLE \\
\hline$[58,60]$ University of Salamanca (USAL) & 2 & MD, VLE \\
\hline [51] University of Seville (US) & 1 & VLE \\
\hline [69] University of Valladolid (UVA) & 1 & VLE \\
\hline$[66,68]$ University of Vigo (UVIGO) & 2 & Video, VLE \\
\hline$[45,48,56]$ National University of Distance Education (UNED) & 3 & VLE \\
\hline [17] Autonomous University of Barcelona (UAB) & 1 & VLE \\
\hline [70] University of Barcelona (UB) & 1 & Web \\
\hline [57] Polytechnic University of Catalonia (UPC) & 1 & PD \\
\hline [50,59] Polytechnic University of Valencia (UPV) & 2 & VLE \\
\hline [47,62] Pompeu Fabra University (UPF) & 2 & MD, VLE \\
\hline
\end{tabular}

The geographical distribution of higher education institutions in Spanish territory (Figure 6) shows that the universities of Barcelona present the greatest number of experiences of good teaching practices with ICT $(n=5)$. This is followed by the universities of Madrid $(n=4)$ and the University of Granada $(n=3)$. The other regions colored on the map show the location of one or two experiences. This is the case of Asturias, Galicia, Cantabria, Salamanca, and Valencia with two experiences each. And León, Valladolid, Badajoz, Alicante, Huelva, Seville, Malaga and Tenerife have one experience each. 


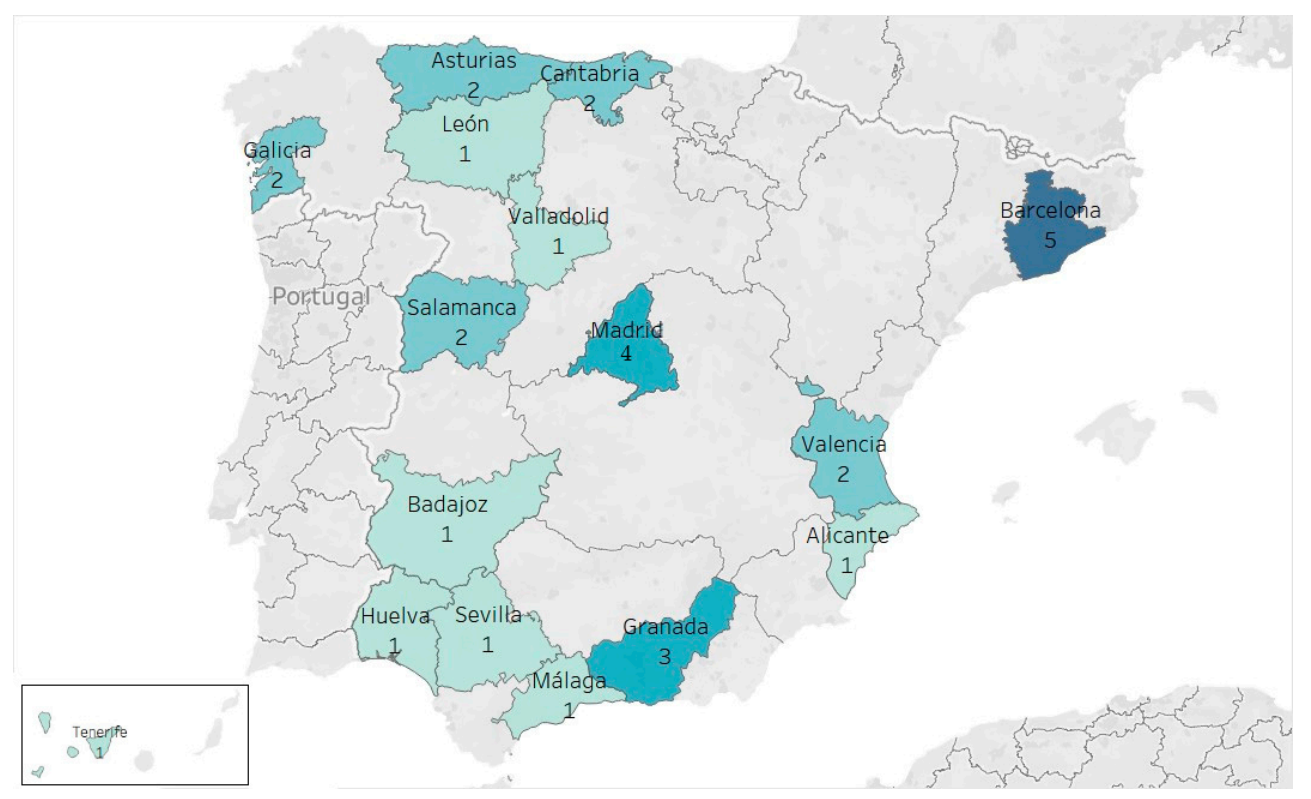

Figure 6. Geographical distribution of good teaching practices with ICT.

\subsection{RQ6. What SDG is Developed in Good Teaching Practices with ICT?}

The approach of good teaching practices with ICT has been placed in the line of SDG \#4 (Quality Education), where most of the experiences are encompassed ( $n=24 ; 88.88 \%)$. On the other hand, a good teaching practice with ICT was proposed to improve all the SDG [45], another one was placed in the line of SDG \#5 (Gender Equality) [67], and another in SDG \#10 (Reduced Inequalities) [47]. The rest of SDG was not reflected in the good teaching practices with ICT carried out. However, the commitment to quality education (\#4) has been the object of interest in the four fields of knowledge where the experiences are located. The rest of SDG has been approached from the Social and Legal Sciences (Figure 7).

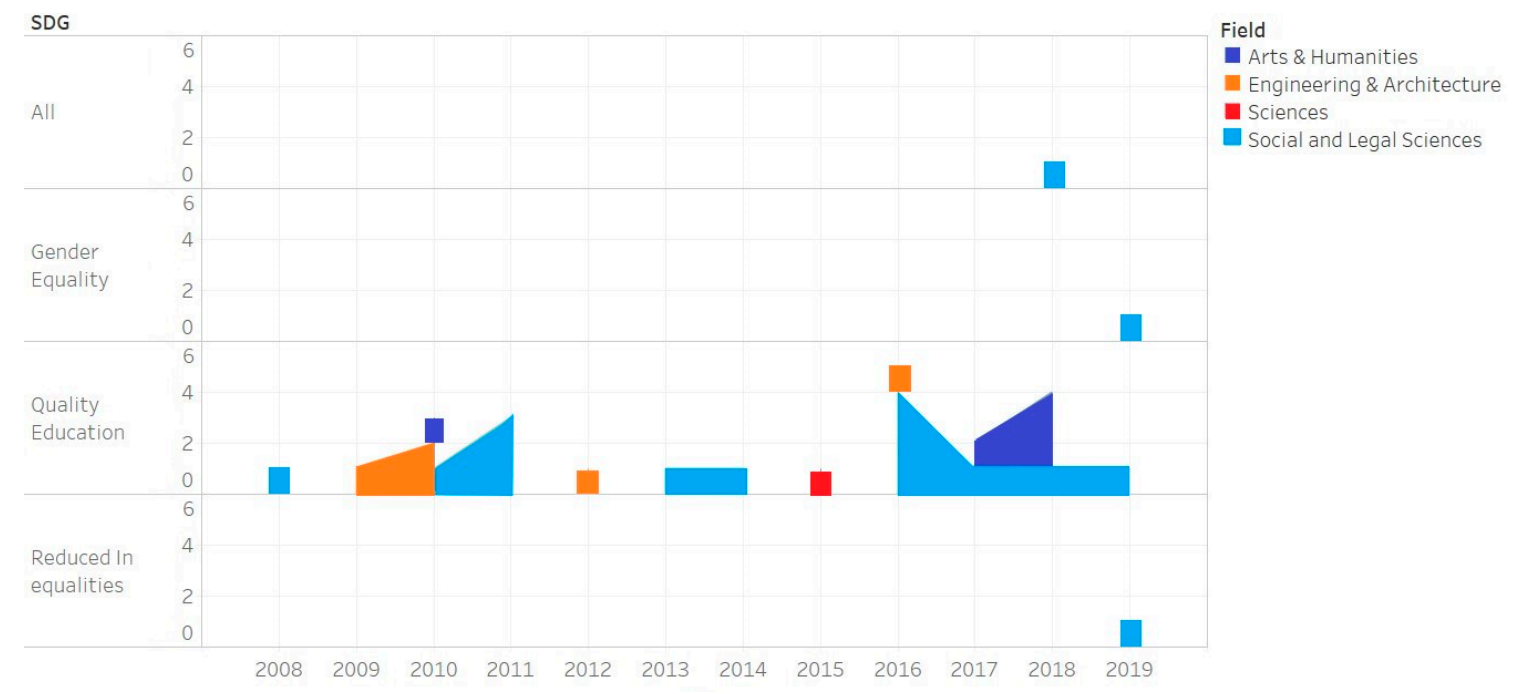

Figure 7. SDG in which good teaching practices with ICT have been identified by field of knowledge. Note: Each color corresponds to a scientific field. The Y axis shows the SDG of the experiences, while the $X$ axis shows the years in which they have been developed. An example for its correct interpretation is the year 2018: this year shows one experience in the field of Social and Legal Sciences, two experiences for Arts and Humanities, both located in the development of SD4 and one experience that develops all SDGs in the field of Social and Legal Sciences. 


\section{Discussion}

The analysis of 27 documents provides an overview of the current state of good teaching practices with ICT in Spanish higher education. The seven key principles of good practice with ICT [23], were present in all good teaching practice experiences. However, the greatest emphasis was found on the common denominator of prioritizing collaborative learning among students.

Regarding the data, Figure 2 shows that scientific production has increased in the last five years, which reflects a trend towards good teaching practices [18]. In addition, the year 2019 at the time of analysis has not been a full year, so there may be a further increase in publications.

For its part, the priority field of knowledge for good teaching practices with ICT is Social and Legal Sciences, where the field of education is framed and practices have been developed continuously over the years and with different technologies (VLE, web, radio, podcasting and mobile devices), as shown in Figure 4. On the other hand, Arts and Humanities present a minor development where only VLE and mobile devices have been applied, with differences in the technologies normally applied in this field of knowledge (forums, blogs and wikis) [17]. To a lesser extent, Engineering and Architecture has rarely developed good teaching practices with ICT, although they have presented a variety of technologies (3D, podcasting, video and VLE). In Sciences, only VLE has been used as a technology. And in the Health Sciences, no good teaching practice with ICT has been collected. Thus, the path has been different depending on the field of knowledge, which is a key determinant of good teaching practices with ICT, as shown in Figures 3 and 4.

In short, the technology used par excellence are the VLE, especially applied in the Social and Legal Sciences [17] and with a stable path over the years. E-learning also plays a major role in higher education [20], combining with face-to-face teaching at universities [4,5,11]. Meanwhile, 3D technology, Radio, and Video have only been used once. Podcasting had its boom during 2009-2011 and good teaching practices with mobile devices have begun to develop during 2018-2019. Thus, the diachronic analysis shown in Figure 5 identifies the past, present, and future of certain technologies, among which are past technology podcasting, present VLE and emerging mobile devices.

Specifically, this use of mobile devices in the classroom would be framed within the mobile learning methodology $[8,13]$. This is a marked trend in the Horizon Report [1], in which university teachers begin to take an interest and implement it as part of their teaching methodology at the Spanish University [9].

On the other hand, the University of Granada and National University of Distance Education are the one that has used the greatest number of experiences and diverse technology in the development of good teaching practices with ICT. In future studies, it would be interesting to analyze the internal policies of the universities where good teaching practices are concentrated in order to see if they encourage these practices with their own programs. At the same time, previous studies focused on the Spanish context have detected good teaching practices in some of the institutions included in this work, which are spread over different regions of the Spanish territory [24-27], as shown in Figure 6.

In relation to the characterization of good teaching practices with ICT, most of the experiences developed use interactive and collaborative VLE. These practices focus on improving student learning, with the aim of serving as reference models for other teachers [21].

Finally, sustainability is acquiring major prominence in educational practices, with an explicit interest in orienting good teaching practices towards sustainable models [34]. RQ6 has addressed the link between good practice and SDG, where it is shown that the majority of good teaching practices with ICT are framed in the development actions of SDG \#4 (Quality Education). So ICT have been emerging as a key resource in this SDG [33]. Only one experience was based on the development of all SDG, another on SDG \#5 (Gender Equality) and another on SDG \#10 (Reduced Inequalities). It should be noted that all fields of knowledge have focused on SDG \#4 [35]. There is a common interest in the improvement of education and related aspects such as gender equality and reduced inequalities, where education plays a fundamental role. 
Finally, this work follows the line of the other previous review studies on good teaching practices [28-31], but focusing on a single aspect that the others had not addressed: good teaching practices with ICT in Spanish higher education.

\section{Conclusions}

The development of good teaching practices with ICT is fundamental to develop reference models that serve teachers who are starting to apply technology in the classroom for the first time. At the same time, sustaining these experiences in the SDG generates a symbiosis along the lines of the Sustainable Development Agenda 2030.

In this systematic review work, a series of documents have been analyzed in order to respond to the objectives set regarding the identification of good teaching practices with ICT that are being developed in Spanish higher education and the establishment of the relationship between good practices and the SDG. The achievement of these objectives was achieved with the response to the different RQs proposed.

Among the limitations of the study is the fact of limiting the search to only two databases (SCOPUS and WOS). However, using only these two databases ensures that the literature with the greatest scientific impact has been reviewed. On the other hand, restricting the search to Spanish higher education has also been another limitation, so in future studies it would be advisable to extend the sample to the whole world. However, the study carried out is a faithful reflection of the current state of Spain with regard to good teaching practices with ICT and served to limit the field of study to a single context. Another limitation found was that we found few concrete experiences (a total of 27), while the rest of the documents discussed joint analyses of good teaching practices with ICT in different universities, but did not specify what these consisted of.

With regard to future lines of research, it is proposed to continue research along these lines and to extend the field of study to other countries, in order to check whether these results also occur in foreign institutions or are a singularity of the Spanish context. Also of interest is the possibility of investigating how good practices relate to SDG.

Finally, moving towards sustainability is a key aspect of 21st century society, and the trend to develop good teaching practices with ICT leads education towards these sustainability principles. Therefore, the challenge for university teachers is to include all these aspects in the teaching they give in the classroom. All this will result in a sustainable use of technology to improve educational quality through good teaching practices, while generating environmental awareness and creating sustainable spaces.

Author Contributions: All authors have contributed equally.

Funding: Asociación para la Investigación y Promoción de la Educación en la Sociedad Digital - PROMOEDUCA (Granada, Spain).

Acknowledgments: To the researchers of the research group AREA (HUM-672). Research group by belonging to the Ministry of Education and Science of the Junta de Andalucía and based in the Department of Didactics and School Organization of the Faculty of Education Sciences of the University of Granada.

Conflicts of Interest: The authors declare no conflict of interest.

\section{References}

1. Alexander, B.; Ashford-Rowe, K.; Barajas-Murphy, N.; Dobbin, G.; Knott, J.; McCormack, M.; Pomerantz, J.; Seilhamer, R.; Weber, N. EDUCAUSE Horizon Report: 2019 Higher Education Edition; EDUCAUSE: Louisville, CO, USA, 2019.

2. García-Peñalvo, F.J. Estado actual de los sistemas e-learning. TESI 2005, 6, 1-6.

3. Durán, R.; Estay, C.A. Formación en buenas prácticas docentes para la educación virtual. RIED 2016, 19, 209-232.

4. Garrison, D.R.; Kanuka, H. Blended learning: Uncovering its transformative potential in higher education. Internet High. Educ. 2004, 7, 95-105. [CrossRef] 
5. Hinojo, F.J.; Aznar, I.; Cáceres, M.P. Student's Perceptions of Blended Learning at University. Comunicar 2009, 17, 165-174. [CrossRef]

6. O'Flaherty, J.; Phillips, C. The use of flipped classrooms in higher education: A scoping review. Internet High. Educ. 2015, 25, 85-95. [CrossRef]

7. Strayer, J.F. How learning in an inverted classroom influences cooperation, innovation and task orientation. Learn. Environ. Res. 2012, 15, 171-193. [CrossRef]

8. Motiwalla, L.F. Mobile learning: A framework and evaluation. Comput. Educ. 2007, 49, 581-596. [CrossRef]

9. Aznar, I.; Cáceres, M.P.; Romero, J.M. Effect of the mobile learning methodology in university education: Meta-analysis of the research published in WOS and Scopus. RISTI 2018. [CrossRef]

10. Piccoli, G.; Ahmad, R.; Ives, B. Web-based virtual learning environments: A research framework and a preliminary assessment of effectiveness in basic it skills training. MIS Q. 2001, 25, 401-426. [CrossRef]

11. Raso, F.; Aznar, I.; Cáceres, M.P. Integration of information and communication technologies: An evaluative study in rural Andalusian schools (Spain). Píxel Bit 2014, 45, 51-64.

12. Bergmann, J.; Sams, A. Flip Your Classroom: Reach Every Student in Every Class Every Day; International Society for Technology in Education: Eugene, OR, USA, 2012.

13. Kukulska-Hulme, A.; Sharples, M.; Milrad, M.; Arnedillo-Sánchez, I.; Vavoula, G. The genesis and development of mobile learning in Europe. In Combining E-Learning and M-Learning: New Applications of Blended Educational Resources; Parsons, D., Ed.; Information Science Reference: Hershey, PA, USA, 2011; pp. 151-177.

14. Méndez, J.M.; Delgado, M. ICT in Primary and Secondary Education Schools in Andalusia. A case study from best practices. Dig. Educ. Rev. 2016, 29, 134-165.

15. Hatlevik, I.K.R.; Hatlevik, O.E. Examining the Relationship between Teachers' ICT Self-Efficacy for Educational Purposes, Collegial Collaboration, Lack of Facilitation and the Use of ICT in Teaching Practice. Front. Psychol. 2018, 9, 935. [CrossRef] [PubMed]

16. Rossi, A.S.; Barajas, M. Digital competence and educational innovation: Challenges and opportunities. Profesorado 2018, 22, 317-339.

17. Mercader, C.; Gairín, J. How do university teachers use digital technologies in class? REDU 2017, 15, $257-273$. [CrossRef]

18. Martínez, F.; González, J. Experiences of teachers belonging to the engineering schools to implement the information and communications technology (ICT) in their face educational practices. Rev. Int. Technol. Educ. 2018, 5, 1-13.

19. Fernández, M.D. Educational emergent model in the good practices ICT. Rev. Fuentes 2016, 18, $33-47$.

20. González-Pérez, A. Pedagogical keys to improve the quality of EHEA. Educatio Siglo XXI 2015, 33, $259-276$. [CrossRef]

21. Durán, R.; Estay-Niculcar, C.; Álvarez, H. Adoption of good virtual education practices in higher education. Aula Abierta 2015, 43, 77-86. [CrossRef]

22. Fernández, C. Innovation for multilingualism: E-lengua. Caracteres 2017, 6, 282-297.

23. Chickering, A.W.; Gamson, Z. Seven Principles for Good Practise in Undergraduate Education; American Association for Higher Education Bulletin: Washington, DC, USA, 1987.

24. Marcelo, C.; Yot, C.; Mayor, C. «Alacena», An Open Learning Design Repository for University Teaching. Comunicar 2011, 19, 37-44. [CrossRef]

25. Cabero, J.; Morales, J.A.; Barroso, J.; Fernández-Batanero, J.M.; Romero, R.; Román, P.; Llorente, C.; Ballesteros, C. Analysis of production resource centers of the Spanish universities' ICT's. Rev. Educ. 2010, 351, 237-257.

26. Martí, C.; Conde, M.; Rosselló, J.J.; López-Polín, C.; Martín, A.; Torrandell, I. Project of good teaching practices with ICT in the Universitat de les Illes Balears. In Buenas Prácticas con TIC Para el EEES; Urbina, S., Coord, Eds.; Universitat de les Illes Balears: Islas Baleares, Spain, 2011; pp. 29-41.

27. Prendes, M.P.; Gutiérrez, I. Spanish University Teachers' Technological Competencies. Rev. Educ. 2013, 361, 196-222.

28. Chaubey, A.; Bhattacharya, B.; Das Mandal, S.K. Attributes of good teaching in engineering education in Indian subcontinent. Sadhana Acad. Proc. Eng. Sci. 2018, 43, 188. [CrossRef]

29. Caldeiro-Pedreira, M.C.; Yot, C.; Castro, A. Detection of mobile devices-based good educational practices in primary school. Pris. Soc. 2018, 20, 58-75. 
30. Estai, M.; Bunt, S. Best teaching practices in anatomy education: A critical review. Ann. Anat. 2016, 208, 151-157. [CrossRef]

31. Olcon, K.; Gilbert, D.J.; Pulliam, R.M. Teaching about Racial and Ethnic Diversity in Social Work Education: A Systematic Review. J. Soc. Work Educ. 2019, in press. [CrossRef]

32. United Nations-UN. Transforming our World: The 2030 Agenda for Sustainable Development; United Nations: New York, NY, USA, 2015.

33. Ortega-Sánchez, D.; Gómez-Trigueros, I.M. Massive Open Online Courses in the Initial Training of Social Science Teachers: Experiences, Methodological Conceptions, and Technological Use for Sustainable Development. Sustainability 2019, 11, 578. [CrossRef]

34. Gasca, G.J.; Organista, J.; López-Ornelas, M. Classification of good practices mediated by mobile technology at a bachelor's degree in translation, Baja California. Rev. Est. Exp. Educ. 2018, 17, 29-49.

35. Cerro, F.; Lozano, F. Ecourban Technical Project supported by ICT for STEM learning (Technical Drawing) and the consolidation of SDG in classroom. RED 2019, 59, 4.

36. Paredes-Parada, W. Good practices in the use of information technology and communication (ITC) in Ecuadorian universities. Cienc. Doc. Tecnol. 2018, 29, 176-200. [CrossRef]

37. García-González, A.; Ramírez-Montoya, M.S. Systematic Mapping of Scientific Production on Open Innovation (2015-2018): Opportunities for Sustainable Training Environments. Sustainability 2019, 11, 1781. [CrossRef]

38. Kitchenham, B.; Pretorius, R.; Budgen, D.; Brereton, O.P.; Turner, M.; Niazi, M.; Linkman, S. Systematic literature reviews in software engineering-a tertiary study. Inf. Softw. Technol. 2010, 52, 792-805. [CrossRef]

39. Kroll, J.; Richardson, I.; Prikladnicki, R.; Audy, J.L.N. Empirical Evidence in Follow the Sun Software Development: A Systematic Mapping Study. Inf. Softw. Technol. 2018, 93, 30-44. [CrossRef]

40. Moher, D.; Liberati, A.; Tetzla, J.; Altman, D.G. PRISMA Group Preferred Reporting Items for Systematic Reviews and Meta-Analyses: The PRISMA Statement. PLoS Med. 2009, 6, e1000097. [CrossRef]

41. Hinojo, F.J.; Aznar, I.; Cáceres, M.P.; Trujillo, J.M.; Romero, J.M. Problematic Internet Use as a Predictor of Eating Disorders in Students: A Systematic Review and Meta-Analysis Study. Nutrients 2019, 11, 2151. [CrossRef]

42. Ballesteros, C.; Cabero, J.; Llorente, M.C.; Morales, J.A. E-learning uses in Andalusian universities: Situation and good practices analysis. Píxel Bit 2010, 37, 7-18.

43. Buzzetto-More, N.; Alade, A.J. Best Practices in e-Assessment. J. Inf. Technol. Educ. Res. 2006, 5, $251-269$. [CrossRef]

44. Bridges, D.R.; Davidson, R.A.; Odegard, P.S.; Maki, I.V.; Tomkowiak, J. Interprofessional collaboration: Three best practice models of interprofessional education. Med. Educ. Online 2011, 16, 6035. [CrossRef]

45. Álvarez-Otero, J.; Lázaro, M.L. Education in Sustainable Development Goals Using the Spatial Data Infrastructures and the TPACK Model. Educ. Sci. 2018, 8, 171. [CrossRef]

46. Área, M.; San Nicolás, M.B.; Fariña, E. Good practices for virtual classroom in universitary blended learning. TESI 2010, 11, 7-31.

47. Barberá, G.; Gelpí, C. The Role of Technologies in Sign Language Learning and their Revitalization. RAEL 2019, 17, 3-19.

48. Bárcena, E.; Martín-Monje, E.; Jordano, M. Methodological and technological innovation in distance teaching of English for Tourism. Ibérica 2016, 31, 39-62.

49. Bernardo, A.M.; Ruiz-Cecilia, R. Designing Technology-Mediated Tasks for Language Teaching: A Methodological Framework. H. U. J. Educ. 2017, 32, 265-279. [CrossRef]

50. Blanc, S.; Benlloch-Dualde, J.V.; Benet, G. Engaging Students in an Undergraduate Computer Technology Course: An Active-Learning Approach. Int. J. Eng. Educ. 2015, 31, 610-618.

51. Cabero, J.; Llorente, M.C.; Morales, J.A. Contributions to e-Learning from a Best Practices Study at Andalusian Universities. RUSC 2013, 10, 226-239.

52. Calvo, A.; Rodríguez-Hoyos, C. Analizying MOOCs from an educational perspective in Spain. Int. J. Educ. Technol. High. Educ. 2016, 13, 13. [CrossRef]

53. Calvo, M.A.; Braga, G.M.; Fueyo, M.A. Opening up the training of education practitioners to the field of MOOC. Results of a research project at the Universities of Cantabria and Oviedo. Profesorado 2019, 23, 259-276. 
54. Contreras, P.; Duarte, A.; Guzmán, M.D. Educommunicative proposals on the Uniradio: From pre primary to university. Edmetic 2016, 5, 182-201.

55. Cruz-Díaz, R.; Ordóñez-Sierra, R.; Román, S.; Pavón, F. Good practices for the development of media competences in socioeducational contexts. Píxel Bit 2016, 48, 97-113. [CrossRef]

56. Escobar, M.A.; Ibáñez, A. ICTS in English for specific purposes: A methodological proposal. Encuentro 2018, 27, 38-52.

57. Fernández, V.; Simo, P.; Sallan, J.M. Podcasting: A new technological tool to facilitate good practice in higher education. Comput. Educ. 2009, 53, 385-392. [CrossRef]

58. García-Alonso, J.L.; Samy, D. Applicability of ICT-supported language teaching in contexts of social integration and international cooperation. ARTÍCULOS Círculo de Lingüística Aplicada a la Comunicación 2018, 76, 101-116. [CrossRef]

59. García, J.; Magal-Royo, T.; Enríquez, E. Teachers' trialing procedures for Computer Assisted Language Testing Implementation. Eur. J. Educ. Res. 2010, 39, 1-18.

60. García-Valcárcel, A. Tutoring in Higher Education and the contribution of the ICT for its improvement. RELIEVE 2008, 14, 1-14.

61. Gutiérrez, P.; Yuste, R.; Delgado, S.; Lucero, M. Collaborate on ICT work applied to education. Profesorado 2011, 15, 179-194.

62. Manathunga, K.; Hernández-Leo, D. Authoring and enactment of mobile pyramid-based collaborative learning activities. Br. J. Educ. Technol. 2018, 49, 262-275. [CrossRef]

63. Mihai, A.; Costea, M.; Sarghie, B.; Almodóvar, E.; Pérez, R.; San Martín, A.; Ferriz, C.M.; de Carvalho, C.V.; Azevedo, C.; Pavlova, L.P.; et al. Inga 3D-Creative transfer of competence in $3 \mathrm{~d}$ footwear cad to vet professionals. Rev. Piel. Incalt. 2016, 16, 43-54. [CrossRef]

64. Moya, R.; Serrano, C.; Tomás, N. Legal employment reality in the classroom. Media self-employment guides. ARBOR 2011, 187, 273-277.

65. O'Dowd, R. Innovations and Challenges in Using Online Communication Technologies in CLIL. Theory Pract. 2018, 57, 232-240. [CrossRef]

66. Pérez Abellás, A.; Sarmiento, J.A.; Zabalza, M.A. The teaching practices of the good teachers of the Vigo University: The technological area. REDU 2012, 10, 145-175. [CrossRef]

67. Pinto, M.; Gómez-Hernández, J.A.; Sales, D.; Cuevas-Cerveró, A.; Fernández-Pascual, R.; Caballero, D.; Navalón, C. Learning and teaching digital skills in a mobile environment: Advances of a research on university professors and students of Social Sciences degree. RICI Rev. Ibero Am. Cienc. Inf. 2019, 12, 585-596.

68. Ricoy, M.C.; Couto, M.J. Best practices with ICT and the value attributed by the students newly integrated in university. Educ. Pesqui. 2014, 40, 897-912. [CrossRef]

69. Rubia, B.; Anguita, R.; Jarrín, I.; Ruiz, I. Educative innovation process in university formation, new productive bests practices in educative technology. TESI 2010, 11, 96-120.

70. Somoza-Fernández, M.; Rodríguez-Parada, C. Web tutorials: Indicators and best practice examples. EPI 2011, 20, 38-46.

(C) 2019 by the authors. Licensee MDPI, Basel, Switzerland. This article is an open access article distributed under the terms and conditions of the Creative Commons Attribution (CC BY) license (http://creativecommons.org/licenses/by/4.0/). 